\title{
Phrasal verbs with off may not be hard to pull off
}

\author{
Svetlana Nedelcheva*
}

\begin{abstract}
This article studies the phrasal verbs $(P V)$ widely used in contemporary English**. They are challenging to foreign language learners not only because they are numerous but also with their multiple meanings. Polysemous phrasal verbs are seen from a new perspective with the development of cognitive linguistics. Researchers apply the cognitive principles to arrange them in systematic groups and to prove that their meanings are not randomly chosen but motivated.
\end{abstract}

The present study focuses on phrasal verbs with OFF and organizes their meanings in a radial network related to one core, invariant meaning. The particle encodes specific conceptualizations of spatial relations non-native speakers of English are unaware of. The article provides some suggestions to teaching PVS using a cognitive-based approach to help EFL learners memorize phrasal verbs more efficiently.

Key words: Cognitive linguistics, corpus linguistics, phrasal verbs, semantic networks, second language acquisition

\section{Introduction}

The collaboration between cognitive linguistics and second language acquisition in recent years has aroused a lot of attention in linguists worldwide. Researchers view cognitive linguistics as setting theoretical guidance and achieving considerable results in the field of second language acquisition, mainly in the following aspects: (1) the prototype in English grammar structure (e.g. Langacker 1987, 1991); (2) the acquisition of metaphor and idioms (e.g. Kovecses, Szabó 1996; Wezhbitska 1997); (3) the acquisition of second language vocabulary (e.g. Csabi 2004; Liao, Fukuya 2004). Vocabulary teaching and learning in second language teaching and research was comparatively neglected for a long time until the late $1980 \mathrm{~s}$, when the application of the developments of the cognitive linguistic theory started. Since then cognitive linguistics have moved the focus of research on vocabulary, which has led to deepening and expanding the understanding of vocabulary nature and conceptualization, thus providing new incentives in the research of second language vocabulary teaching (Hatch, Brown 1995).

Linguists and EFL teachers have long recognized that the acquisition of particles

\footnotetext{
* University of Shumen, Department of English Studies, Shumen, Bulgaria

** In linguistics phrasal verbs are also called verb-particle constructions (VPSs). In this study the two terms are used interchangeably.
} 
poses major problems to non-native speakers of English (e.g. Celce-Murcia, Larsen-Freeman 1999; Tyler, Evans 2003). Rudzka-Ostyn claims about PVs that: "although they are common in spoken and written English and new ones are constantly being created, they do not enjoy a good reputation for EFL learners" (2003: 1). Naturally, EFL learners, even the advanced ones, tend to avoid them in their oral communication and writing production. Memorizing long lists of PVs does not guarantee their incorporation into the active vocabulary of the learner and using them in practice (Dainty 1992).

Cognitive linguistics (CL) offers an alternative perspective to the traditional approach, suggesting that the many distinct meanings associated with a particular particle are motivated and related in systematic principled ways (Lindner 1982; Lakoff 1987; Tyler, Evans 2001, 2003; Evans, Tyler 2005). Hence, this approach suggests a cognitive mechanism of learning PVs without relying on tedious memorization and repetition. The main tenet of CL, namely the embodiment principle, argues that human cognition is structured and expands as a result of bodily perceptions and experiences due to our interaction with the world around us (Johnson 1987; Lakoff, Johnson 1980, 1999; Johnson, Rohrer 2007). The human perceptual system conceptualizes spatial scenes in terms of foreground and background, or trajector (TR) and landmark (LM) (Langacker 1987). The TR tends to be the smaller, more moveable element which is the focus of attention, while the LM is the larger, less moveable, locating element.

Lindstromberg (1997) studies verb particles in opposition to each other. He states that up and off can combine with the same verbs.

But in such contexts off seldom functions as anything like an opposite to up despite the fact that (because of gravity) being off a supporting surface results in being 'down'. Rather, off is still the opposite of on. Another important difference between off and down is that off has even stronger negative connotations. (Lindstromberg 1997: 192)

CL contributes to the study of particles in that particles provide a system for explaining spatial relations in English. Most typically they are conceptualized as a configuration of a focus element (the TR) and a locating or ground element (the LM). This basic spatial meaning of a particle gives rise to additional senses some of which are non-spatial (Tyler, Evans 2003; Evans, Tyler 2005). Thus, the multiple meanings develop a complicated radial network which shows how they are related systematically. We go a step further and claim that all the verbs that combine with a particular particle can be organized in a motivated way into a semantic network. These systematic networks, which draw on human interaction with the physical world, have the potential to help EFL learners in mastering the complicated PVs. 


\section{Corpus study of $O F F$}

The corpus of this study is collected from two different sources. On the one hand, we work with Longman Phrasal Verbs Dictionary (2000) which contains 229 phrasal verbs with off. They are extracted together with their meanings, exemplary sentences and synonyms and set up in a table for easier processing (see Figure 1).

On the other hand, we use Wiktionary - the free dictionary* and more specifically its category "English phrasal verbs with particle (off)". This source suggests 218 VPCs with off arranged in a list and each of the verbs has a link with its meaning attached to it. All the meanings were extracted manually and organized in a table together with an example, which illustrated the corresponding meaning in a context (see Figure 2). Because of the difference in number the two corpora were compared in order to unify the corpus. The procedure revealed unexpected results as in the Longman dictionary $74 \mathrm{PVs}$ were found that were not present in Wiktionary. The Wiktionary, in its turn, showed 55 PVs missing in the Longman PV dictionary (see Appendix 1). As a consequence, 292 VPCs with off were analyzed.

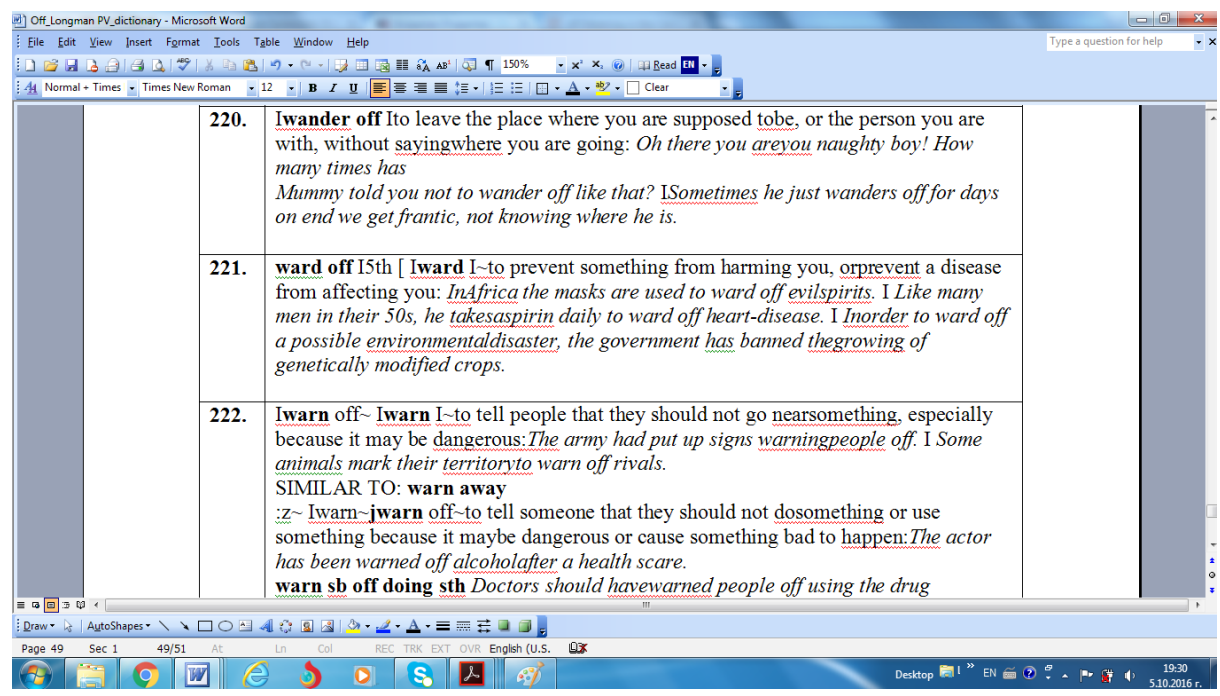

Fig. 1. Longman Phrasal Verbs Dictionary sample

\footnotetext{
*http://en.wiktionary.org/wiki/Category:English_phrasal_verbs_with_
} particle_\%28off\%29 


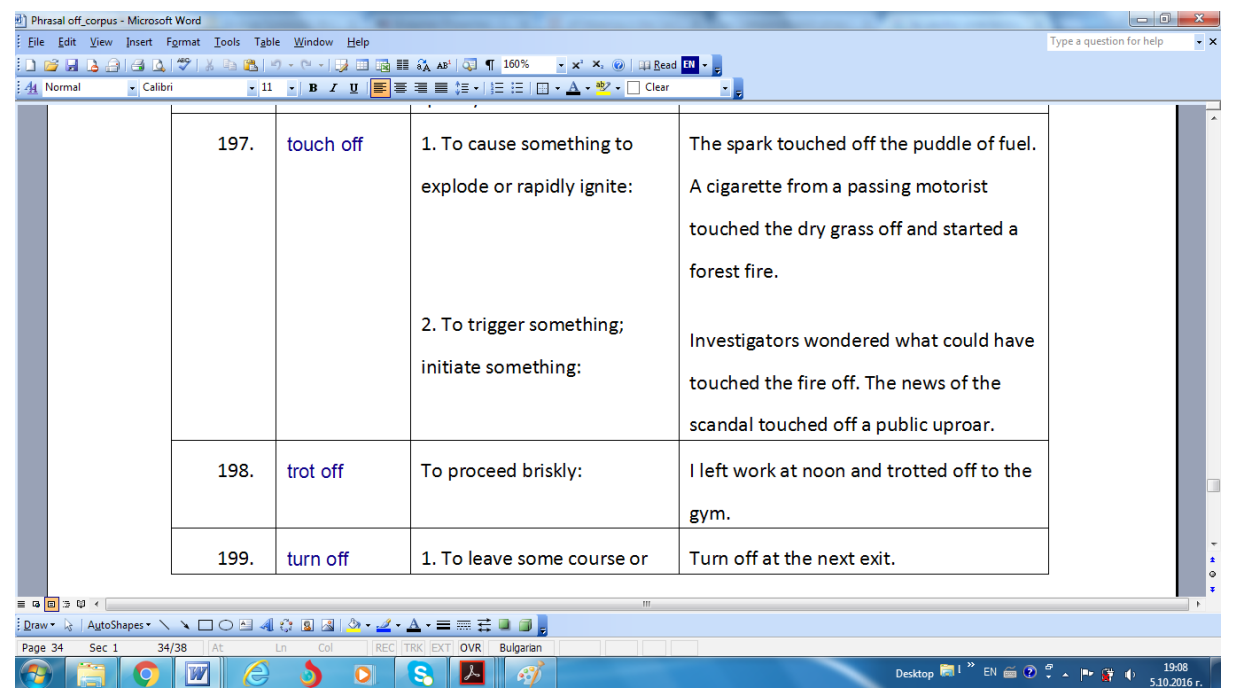

Fig. 2. Wiktionary corpus sample

\section{Semantic network of $\mathrm{OFF}$}

As a matter of fact, the meaning of the PVs usually cannot be identified as a symbiosis of the meaning of the verb and the meaning of the particle. Therefore, they are widely believed to be arbitrary and unsystematic lexical items that have to be learned one by one - a very difficult and time consuming task. For instance, even beginners know what put means and what off means, but that will not help them much to guess the various meanings of put off. What is more, the Longman PV dictionary gives 6 different meanings of put off*:

1. to delay doing something until later...: Why don't you talk to him about it? You can't keep putting it off forever.

\section{* SIMILAR TO: postpone, put back}

2. $\sim$ to stop someone from liking another person or thing or stop them from being interested in it: Don't be put off by the name. It's actually a very pretty plant.

My last boyfriend put me off men for life.

3. to make a light stop working by pressing a switch: Don't forget to put off the lights when you leave.

* SIMILAR TO: put out, switch out, turn out

4. $\sim$ to delay meeting someone, talking to someone, paying someone, etc., because you do not want to do it until later: Maybe 1 should go and see him. 1 can't put him off much longer.

\footnotetext{
* This is an abridged version. To see all the details look up Longman Phrasal Verbs Dictionary (2000).
} 
5. especially BrE to make it difficult for someone to pay attention to what they are doing, for example by talking or making a noise: Stop giggling! You're putting me off.

* SIMILAR TO: distract

6. $\sim B r E$ if a bus or taxi driver puts you off somewhere, they stop the bus or taxi at a particular place and allow you to get out there: Do you want me to put you off at the station?

* SIMILAR TO: drop off, set down

In this study we suggest that all verb-particle constructions with $O F F$ share the same semantic network. In order to test our hypothesis we follow a procedure of three steps:

1. We construct the semantic network of the adverb $O F F$.

2. Using it we construct the semantic network of the polysemous verb put off.

3. We apply the semantic network to a cross section of 20 verbs excerpted from the corpus.

If we look for the invariant (also called core) meaning of off we should turn to the adverb off which is generally described in Cambridge dictionary ${ }^{*}$ with 8 different meanings: 1. away from, 2. removed, 3. not operating, 4. less money, 5. not at work, 6. separated, 7. completely, 8. get rid off. Some of the suggested meanings are synonymous, namely away from, removed, separated. This fact can be observed clearly in the sentences suggested as examples:

1. away from - He drove off at the most incredible speed ${ }^{* *}$.

2. removed - Take your jacket off.

6. separated - The area in the park where the kids play is fenced off for safety reasons.

They can be joined together under the title 'AWAY' as it is an underlying meaning of the three of them ${ }^{* * *}$.

8. Get rid of can be related to the same cluster as it is associated with something present that we would like to remove, for instance: We went out for a while to walk off some of our dinner.

What is meant by rubric 7. completely is that something is taken away so that

\footnotetext{
* http://dictionary.cambridge.org/dictionary/english/off

** The examples illustrating the different meanings of OFF are taken from Cambridge Dictionary (see footnote 4)

*** 'AWAY' is the name of a semantic cluster and it is spelled with capital letters.
} 
nothing is left or something is exhausted and, therefore, finished:

It says on the bottle that it kills off all known germs.

The good thing about exercise is that it burns off calories.

As all examples in this group refer to taking something away until it is finished, we'd rather name this group 'finished' than 'completely'. It is metaphorically related to the 'removed' group: killing off germs and burning off calories make them disappear. In a different situation the thing that is taken away can be money. When some money is taken away what is left is less money than the initial sum, hence rubric 4. 'less money'.

You can get some money off if you pay cash.

There was $\$ 40$ or $\$ 50$ off most jackets in the store.

When you have to pay that sum of money it is preferable in all cases to give away the lower price.

Another cluster of meanings can be formed by 3. 'not operating' and 5. 'not at work'. They can be united under the title 'NOT WORKING', for example:

not operating - Make sure the computers are all off before you go home.

not at work - I'm going to take/have some time off to work on my house.

The difference between the two members of the cluster lies only in the type of referent. The class that is 'not operating' are inanimate objects, mostly machines of various kinds. Primarily people belong to the section 'not at work'. The relation between the two clusters is not obvious at first glance. But if we think of the fact that machines need a continuous input of energy in order to work, removing that energy will interrupt their operation. Similarly, people use up less energy or no energy at all when they are not at work. Consequently, some of the energy is away, not present, in these particular situations. The semantic network of $O F F$ can be summarized in a diagram (see Figure 3): 


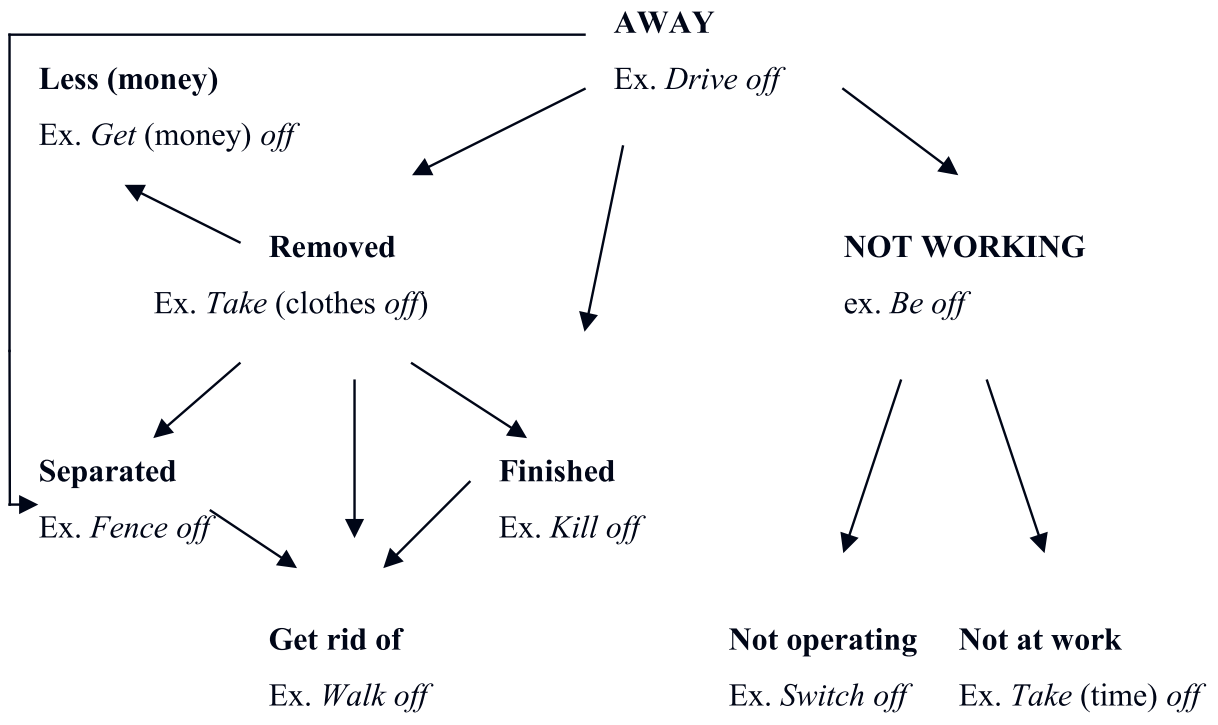

Fig. 3. The semantic network of $O F F$

The analysis of the meanings of the adverb $O F F$ shows that all its meanings are related in a motivated and systematic way. As a next step we suggest going back to the polysemous verb put off and see if the network of meanings of $O F F$ applies to its various uses. We hypothesize that some of the sections may not be filled in, but as a whole there will not be considerable differences in the networks of the polysemous adverb $O F F$ and the verb put off.

1. $\sim$ to delay doing something until later... The event is removed away from the present moment and pushed to a moment in the future. The meaning falls in the section AWAY and we can add the specific feature 'away in time'.

2. $\sim$ to stop someone from liking another person or thing... When someone is stopped from liking another person, most probably the two people do not see each other very often, they are separated. Then we can associate the meaning with the section 'separated'.

3. $\sim$ to make a light stop working by pressing a switch. This meaning can be attributed to the section 'not operating' because it refers to a mechanism.

4. to delay meeting someone, talking to someone, paying someone etc. because you do not want to do it until later: AWAY (in time). The only difference with the first meaning is that the entity put away is a person not something inanimate or abstract.

5. especially BrE to distract s.o. It can be interpreted as taking away s.o.'s attention: AWAY (abstract)

6. $\sim B r E$ if a bus or taxi driver puts you off somewhere, they stop the bus or taxi 
at a particular place and allow you to get out there ... That will be the place where your trip finishes, thus the meaning goes to the section 'finished'.

Having in mind the semantic network of the adverb $O F F$, we can construct the semantic network of put off (see Fig. 4).

\section{Away in time}

Ex. Postpone
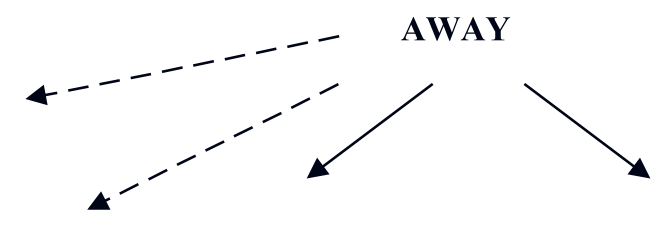

Away abstract

Removed

NOT WORKING

Ex. Distract

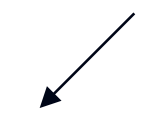

Separated

Ex. Stop from liking

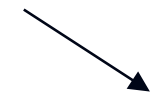

Finished

Ex. Drop off

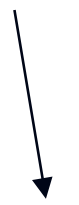

Not operating

Ex. Switch off

Fig. 4. The semantic network of put off

The figure shows that, on the one hand, some of the slots have remained empty, namely 'removed', 'less (money)', 'not at work', 'get rid off'. On the other hand, two additional slots were opened: 'away in time' and 'away abstract'. They are not conceptualized as separate meanings, rather as subtypes of the meaning of AWAY, therefore the arrows that lead to them are dashed.

The last step is to test if the created network of $O F F$ applies to all phrasal verbs which combine with this particle. This will help us organize them in a systematic way. Due to the limited size of this paper, we are going to take a cross section of 20 verbs and study their meanings on the basis of the semantic network (see Table 1)*.

\footnotetext{
* None of the verbs exhibited a meaning in the section 'get rid of', so it is excluded from the table.
} 


\begin{tabular}{|c|c|c|c|c|c|}
\hline $\begin{array}{l}\text { AWAY 'in space, } \\
\text { time and abstract' }\end{array}$ & Removed & Separated & Finished & Less & $\begin{array}{c}\text { NOT } \\
\text { WORKING }\end{array}$ \\
\hline \multirow[t]{2}{*}{$\begin{array}{l}\text { Back off } \\
\text { 'move away' }\end{array}$} & & $\begin{array}{l}\text { Back off } \\
\text { 'back away' }\end{array}$ & $\begin{array}{l}\text { Back off } \\
\text { 'lay off' }\end{array}$ & & \\
\hline & & $\begin{array}{l}\text { Break off } \\
\text { 'separate a part } \\
\text { from the whole' }\end{array}$ & $\begin{array}{l}\text { Break off } \\
\text { 'stop communications, } \\
\text { a relationship, etc.' }\end{array}$ & & \\
\hline \multirow[t]{2}{*}{$\begin{array}{l}\text { Call off } \\
\text { 'cancel' }\end{array}$} & & & $\begin{array}{l}\text { Call off } \\
\text { 'abandon', 'stop' }\end{array}$ & & \\
\hline & & & $\begin{array}{l}\text { Come off } \\
\text { 'stop taking drugs', } \\
\text { 'stop thinking of', 'end } \\
\text { up as' }\end{array}$ & & $\begin{array}{l}\text { Come off } \\
\text { 'stop working' }\end{array}$ \\
\hline $\begin{array}{l}\text { Drop off } \\
\text { 'away from a state' }\end{array}$ & & & $\begin{array}{l}\text { Drop off } \\
\text { 'end a trip' }\end{array}$ & $\begin{array}{l}\text { Drop off } \\
\text { 'less in } \\
\text { number' }\end{array}$ & \\
\hline $\begin{array}{l}\text { Get off } \\
\text { 'leave a place', 'go } \\
\text { away unpunished', } \\
\text { 'send off' }\end{array}$ & & $\begin{array}{l}\text { Get off } \\
\text { 'stop talking on } \\
\text { the phone', 'stop } \\
\text { touching' }\end{array}$ & $\begin{array}{l}\text { Get off } \\
\text { 'end a trip', 'stop } \\
\text { taking drugs' }\end{array}$ & & $\begin{array}{l}\text { Get off } \\
\text { 'finish working' }\end{array}$ \\
\hline $\begin{array}{l}\text { Go off } \\
\text { 'leave a place' } \\
\text { 'explode (also } \\
\text { metaphorically)' } \\
\text { 'shoot' } \\
\text { 's.th. passes } \\
\text { successfully' } \\
\text { 'become worse in } \\
\text { quality' }\end{array}$ & $\begin{array}{l}\text { Go off } \\
\text { (food) } \\
\text { 'good taste } \\
\text { disappears' }\end{array}$ & $\begin{array}{l}\text { Go off s.o. } \\
\text { 'stop liking' } \\
\text { 'change the } \\
\text { topic, direction' }\end{array}$ & & & $\begin{array}{l}\text { Go off } \\
\text { (a machine) } \\
\text { 'stops working' }\end{array}$ \\
\hline $\begin{array}{l}\text { Keep off } \\
\text { 'do not discuss a } \\
\text { topic', 'do not start } \\
\text { s.th.', 'do not gain } \\
\text { weight' }\end{array}$ & & $\begin{array}{l}\text { Keep off } \\
\text { 'do not touch' } \\
\text { 'do not eat' }\end{array}$ & & & \\
\hline \multirow{2}{*}{$\begin{array}{l}\text { Let off } \\
\text { 'not to punish', 'get } \\
\text { away from a job', } \\
\text { 'explode, shoot, } \\
\text { fart', 'rent premises } \\
\text { to s.o.', 'produce } \\
\text { heat' }\end{array}$} & & & $\begin{array}{l}\text { Let off } \\
\text { 'end a trip' }\end{array}$ & & \\
\hline & $\begin{array}{l}\text { Polish off } \\
\text { 'clean' }\end{array}$ & & $\begin{array}{l}\text { Polish off } \\
\text { 'finish food, drink', } \\
\text { 'defeat' }\end{array}$ & & \\
\hline $\begin{array}{l}\text { Push off } \\
\text { 'go away' }\end{array}$ & & $\begin{array}{l}\text { Push off } \\
\text { 'push against' }\end{array}$ & & & \\
\hline
\end{tabular}




\begin{tabular}{|c|c|c|c|c|c|}
\hline $\begin{array}{l}\text { AWAY 'in space, } \\
\text { time and abstract' }\end{array}$ & Removed & Separated & Finished & Less & $\begin{array}{c}\text { NOT } \\
\text { WORKING }\end{array}$ \\
\hline \multicolumn{6}{|l|}{$\begin{array}{l}\text { Run off } \\
\text { 'leave a place', } \\
\text { 'print out', } \\
\text { 'consume power', } \\
\text { 'write quickly and } \\
\text { easily' }\end{array}$} \\
\hline $\begin{array}{l}\text { See off } \\
\text { 'say goodbye to } \\
\text { s.o.', 'chase way' }\end{array}$ & & & $\begin{array}{l}\text { See off } \\
\text { 'defeat', 'kill' }\end{array}$ & & \\
\hline $\begin{array}{l}\text { Set off } \\
\text { 'leave a place', } \\
\text { 'explode', 'trigger } \\
\text { off (metaphorical)' }\end{array}$ & $\begin{array}{l}\text { Set off } \\
\text { 'stand out' }\end{array}$ & & & $\begin{array}{l}\text { Set off } \\
\text { 'reduce tax' }\end{array}$ & \\
\hline \multicolumn{6}{|l|}{$\begin{array}{l}\text { Start off } \\
\text { 'change of state', } \\
\text { 'make s.o. change } \\
\text { their state', 'change } \\
\text { in life', 'leave a } \\
\text { place', 'burst with } \\
\text { laughter' }\end{array}$} \\
\hline $\begin{array}{l}\text { Take off } \\
\text { 'leave the ground', } \\
\text { 'spend time away } \\
\text { from work', 'leave a } \\
\text { place', 'change in } \\
\text { career', 'stop s.o. } \\
\text { who is doing s.th.' }\end{array}$ & $\begin{array}{l}\text { Take off } \\
\text { 'remove } \\
\text { clothes' }\end{array}$ & & $\begin{array}{l}\text { Take off } \\
\text { 'stop taking a } \\
\text { medicine', 'stop } \\
\text { a transportation } \\
\text { service', 'stop a show } \\
\text { from broadcasting' }\end{array}$ & $\begin{array}{l}\text { Take off } \\
\text { 'detract s.o.', } \\
\text { 'deduct' }\end{array}$ & \\
\hline $\begin{array}{l}\text { Turn off } \\
\text { 'leave a road' }\end{array}$ & & $\begin{array}{l}\text { Turn off } \\
\text { 'stop from liking', } \\
\text { 'stop from being } \\
\text { attractive' }\end{array}$ & & & \\
\hline \multicolumn{6}{|l|}{$\begin{array}{l}\text { Work off } \\
\text { 'use energy', } \\
\text { 'consume power' }\end{array}$} \\
\hline $\begin{array}{l}\text { Write off } \\
\text { 'send off', 'dismiss' }\end{array}$ & & & $\begin{array}{l}\text { Write off } \\
\text { 'badly damaged } \\
\text { vehicle not worth } \\
\text { repairing', 'a debt no } \\
\text { longer has to be paid' }\end{array}$ & $\begin{array}{l}\text { Write off } \\
\text { 'reduce tax' }\end{array}$ & \\
\hline
\end{tabular}

Table 1. Polysemous PVs with $O F F$ and their semantic meanings

The verbs analyzed in the table prove the hypothesis that the verb-particle constructions with $O F F$ fit in the semantic network of the adverb $O F F$. As it is obvious from the table, the different meanings of a particular phrasal verb fill in up to four slots in the semantic network although for some of them there are up to 10 meanings enlisted in the Longman PV dictionary. The discrepancy is due to the fact that in some cases there are two or even three meanings belonging 
to the same slot differentiated only in the shades of their meaning. For instance, the AWAY meanings of take off 'leave the ground', 'leave a place', 'spend time away from work', 'change in career', 'stop s.o. who is doing s.th.' are all related to AWAY because, for instance, leaving a place is more general and leaving the ground is more specific, but both refer to the same activity 'to depart from a location'. When a person leaves a place and that is the place of their work they can have a holiday. If the 'place' is metaphorically their career they can start a different job. Another metaphorical interpretation of a 'place' can be the activity a person is occupied with. If another person stops him/her from doing something they make them leave that place and move to a different one.

There are a number of verbs in the table, namely go off, set off, start off, which have meanings associated with starting an activity. This meaning can certainly be seen as opposite to the 'finished' meaning. However, they can be interpreted in a very abstract way. The AWAY category, where these meanings belong, is conceptualized as moving away from one state and entering another. If the initial state is that of a rest the new one can be a certain activity. Then there is a relation between 'moving away from' and 'starting an activity'.

Another conceptual relation can be found between moving away and exploding in the sense of the verbs go off, let off and set off. When a gun fires a bullet goes away from it. When a bomb explodes parts of it go up in the air together with everything around it. Therefore, there is an associative link between exploding and moving away. The same applies to the metaphorical meaning of start off 'burst with laughter', although the thing that goes away with it is noise, which is not something substantial.

Run off and work off are synonymous in the meaning to 'consume power'. We conceptualize it as related to the AWAY meaning because when energy is used it goes away from the source and into the consumer. It is also associated with the 'less' sense as being supplied with energy presupposes its diminishing.

Polish off has developed two metaphorical meanings in the 'finished' sense: 'finish food, drink' and 'defeat' additionally to the 'clean' meaning in the section 'removed'. Finishing one's food or drink is close in a way to cleaning the plate or glass they were served in. They are left clean of their content. Defeating one's enemies can be interpreted as 'finishing' them because they will be no longer present to threaten people. Then this meaning is also related to 'get rid off'.

The limited size of this paper does not allow us to discuss each meaning of each phrasal verb with $O F F$. Hence, we chose to group them and focused on those meanings that seemed unexpected. We also looked for some counter examples in the database to validate the theory of the common semantic network of $O F F$. One of the meanings of the verb face off is widely used in American English in the context of ice hockey and lacrosse to mark the start of the game. It can be 
compared to kick off in football. Kick off, however, is easy to be interpreted from the point of view of the AWAY sense considering that the ball is kicked away by a player. The same line of thoughts cannot be applied to face off. We turned to the etymological dictionaries to decipher the origin of this VPC.

The Old English Dictionary (OED) doesn't discuss a modern sense of the phrasal verb. The only verb uses of face off are from 1958 referring to lacrosse with the ball as a direct object, and an example from 1887 in which it has the sense of "to turn aside (spec. the current of a stream)". The oldest meaning cited is the one that leads us to the AWAY sense. The ball in lacrosse and the puck in ice hockey are hit aside with the start of the game. Therefore, face off is not a counter example because it fits in the semantic network, although the line of conceptualization is not obvious from contemporary point of view.

The modern intransitive sense of face off is 'to confront', e.g. "They faced off across the conference table". Two lines of conceptualization can be found in relation to this meaning of face off. On the one hand, it is linked to the sports term, but not so much to its meaning 'to start a game' than to the situation in which it is used: two players of opposite teams confronting each other. On the other hand, it can be affected by the oldest meaning of the verb to face "confront with assurance; show a bold face', mid-15c**.

When discussing face off there is an inevitable allusion with an interesting play on words in the title of the American science fiction action film Face/ Off (1997), starring John Travolta and Nicolas Cage, directed by John Woo. In the film Travolta plays an FBI agent and Cage plays a terrorist. Both are sworn enemies who undergo face-swap through a complicated experimental transplant procedure. Interpreting the title, we see a literal use of the lexical units face and off. The protagonists' faces were removed and exchanged. However, another point that is also exploited by the director is the idiomatic meaning of face off - 'to confront, argue, or compete against each other'. The two opponents in the movie Sean Archer (Travolta) and Castor Troy (Cage) are in a face-off situation in both meanings of the phrasal verb.

\section{Conclusion}

This article focuses on the usefulness of the conceptual basis for studying PVs. Contrary to the traditional approach, which suggests memorization of lists of PVs as a suitable strategy, the cognitive approach lays emphasis on the particle in the PV as determining the meaning of the construction (Tyler, Evans 2003).

Particles, from a CL viewpoint, have a primary spatial meaning and additional

\footnotetext{
* http://www.wordorigins.org/index.php/forums/viewthread/513

** http://www.etymonline.com/index.php?allowed_in_frame $=0 \& \operatorname{search}=$ face + off
} 
non-spatial abstract meanings. As the semantic network of $O F F$ shows, it has an invariant spatial meaning (AWAY, separated) and a number of non-spatial meanings (e.g. less, get rid of, NOT WORKING). These meanings derive from embodied experience and cognitive mechanisms through which a particle is conceptualized. Native speakers of English are subconsciously aware of such conceptualizations due to their bodily and sociocultural experience within their language community. Non-native learners of English are not familiar with the way the particles are conceptualized in the English language and this leads to a number of problems in learning and using them productively. A favorable way to overcome such problems is showing EFL learners that such conceptualizations exist. Recognizing the connection between the literal and idiomatic meanings of PVs in English via metaphors can greatly contribute to their better understanding.

This article is far from exhaustive in revealing the conceptualizations of all the verbs, however, the study suggests that presenting the conceptual basis of $O F F$ can help foreigners enhance their ability to infer the meaning of novel PVs with the same particle from another one they already know. Further empirical studies, however, are necessary to test the usefulness of $\mathrm{CL}$ approach in different contexts, with various informants, and on different English particles.

\section{References:}

Celce-Murcia, Larsen-Freeman 1999. Celce-Murcia M., D. Larsen-Freeman. The Grammar Book: an ESL/EFLteacher's Course. Boston: Heinle and Heinle, 1999.

Csabi 2004. Csabi S. "A Cognitive Linguistic View of Polysemy in English and its Implication for Teaching". In Achard M., S. Niemeier. (Eds). Cognitive Linguistics, Second Language Acquisition, and Foreign Language. Berlin, New York: Mouton de Gruyter, 2004. 233-256.

Dainty 1992. Dainty P. Phrasal Verbs in Context. London: Macmillan Education, 1992.

Evans 2006. Evans V. Cognitive Linguistics. Retrieved April 3, 2012, from

$<$ http://wires.wiley.com/WileyCDA/WiresIssue/wisId-WCS_3_2.html>.

Evans, Tyler 2005. Evans V., A. Tyler. Applying Cognitive Linguistics to Pedagogical Grammar: The English Prepositions of Verticality. Retrieved May 12, 2012, from < http:// www.vyvevans.net/applycoglxpedagogy.pdf $>$.

Hatch, Brown 1995. Hatch E., C. Brown. Vocabulary, Semantics and Language Education. Cambridge: Cambridge University Press, 1995.

Johnson, Rohrer 2007. Johnson M., T. Rohrer. "We Are Live Creatures: Embodiment, American Pragmatism, and the Cognitive Organism". Body, Language, and Mind. (1), 2007. 17-54.

Kövecses, Szabó 1996. Kövecses, Z., P. Szabó. “Idioms: A View from Cognitive Semantics”. Applied Linguistics (17), 1996. 326-335.

Lakoff 1987. Lakoff G. Women, Fire, and Dangerous Things: What Categories Reveal about the Mind. Chicago: University of Chicago Press, 1987. 
Lakoff, Johnson 1980. Lakoff G., M. Johnson. Metaphors We Live by. Chicago: University of Chicago Press, 1980.

Lakoff, Johnson 1999. Lakoff, G., M. Johnson. Philosophy in the Flesh: The Embodied Mind and its Challenge to Western Thought. Chicago: Basic Books, 1999.

Langacker 1987. Langacker R. W. Foundations of Cognitive Grammar. Theoretical Prerequisites. Vol. I. Stanford: Stanford University Press, 1987.

Langacker 1991. Langacker R. W. Foundations of Cognitive Grammar. Vol. II. Stanford: Stanford University Press, 1991.

Liao, Fukuya 2004. Liao, Y., Fukuya, Y. “Avoidance of Phrasal Verbs: The Case of Chinese Learners of English". Language learning, 54(2), 2004. 193-226.

Lindner 1982. Lindner S. "What Goes up doesn't Necessarily Come Down: The Ins and Outs of Opposite". CLS, 8, 1982. 305-323.

Lindstromberg 1997. Lindstromberg S. English Prepositions Explained. Amsterdam: John Benjamins Publishing Co, 1997.

Rudzka-Ostyn 2003. Rudzka-Ostyn B. Word Power: Phrasal Verbs and Compounds. Berlin/New York: Mouton de Gruyter, 2003.

Tyler, Evans 2001. Tyler A., V. Evans. "The relation between experience, conceptual structure and meaning: nontemporal uses of tense and language teaching". In Pütz M., Niemeier S., R. Dirven (Eds.). Applied Cognitive Linguistics I: Theory and Language Acquisition. Berlin: Mouton de Gruyter, 2001. 63-108.

Tyler, Evans 2003. Tyler A., V. Evans. The Semantics of English Prepositions: Spatial Scenes, Embodied Meaning and Cognition. Cambridge: Cambridge University Press, 2003.

Wierzbicka 1997. Wierzbicka A. Understanding Cultures Through Their Key Words: English, Russian, Polish, German, Japanese. New York: Oxford University Press, 1997.

DICTIONARIES

Cambridge dictionary, Retrieved 12 June 2016, from <http://dictionary.cambridge.org/ dictionary/english/off $>$.

Longman Phrasal Verbs Dictionary. 2000. Retrieved 12 June 2016, from <http://www. longman.com/dictionaries>.

Old English Dictionary. Retrieved 16 June 2016, from <http://www.wordorigins.org/ index.php/forums/viewthread/513>.

Online Etymology Dictionary. Retrieved 2 July 2016, from <http://www.etymonline.com/ index.php?allowed_in_frame $=0 \&$ search $=$ face + off $>$.

Wiktionary - the free dictionary. Retrieved 2 June 2016, from <http:/en.wiktionary.org/ wiki/Category:English_phrasal_verbs_with_particle_\%28off\%29>.

Appendix 1. PVs in the Longman PV dictionary which are not found in Wiktionary and vice versa

\begin{tabular}{|l|l|l|l|}
\hline \multicolumn{2}{|c|}{ OFF - Longman PV Dictionary } & \multicolumn{2}{c|}{ OFF - Wiktionary } \\
\hline Box off & Be brassed off & Bar off & Bear off \\
\hline Be browned of & Bully of & Bitch off & Boil off \\
\hline Burn off & Bump of & Buck off & Bump off \\
\hline
\end{tabular}




\begin{tabular}{|c|c|c|c|}
\hline \multicolumn{2}{|c|}{ OFF - Longman PV Dictionary } & \multicolumn{2}{|c|}{ OFF - Wiktionary } \\
\hline Bundle off & Be cheesed off & Bundle off & Cap off \\
\hline Chop off & Cone off & Chalk off & Chew off \\
\hline Curtain off & Dine off & Cook off & Damp off \\
\hline Divide off & Drag off & Do off & Drink off \\
\hline Drain off & Fling off & Fair off & Fence off \\
\hline Hare off & Haul off & Fend off & File off \\
\hline Have off & Hit off & Fly off & Foist off \\
\hline Hop off & Keep off & Fork off & Jerk off \\
\hline Lead off & Let off & Key off & Laugh off \\
\hline Lift off & Log off & Lie off & Lap off \\
\hline Lop off & Mark off & Mouth off & Mug off \\
\hline Measure off & Move off & Naff off & Pee off \\
\hline Order off & Pace off & Power off & Rack off \\
\hline Partition off & Pension off & Rhyme off & Rust off \\
\hline Ponce off & Post off & Sag off & Scale off \\
\hline Pour off & Print off & Scrape off & Screw off \\
\hline Raffle off & Rush off & Slack off & Slacken off \\
\hline Screen off & Seal off & Sling off & Smart off \\
\hline Section off & Separate off & Spark off & Stomp off \\
\hline Shave off & Shear off & Suck off & Sweat off \\
\hline Ship off & Shuck off & Tag off & Tape off \\
\hline Shuffle off & Shut off & Toddle off & Waft off \\
\hline Sign off & Siphon off & Wank off & Whip off \\
\hline Skip off & Slice off & Whisk off & Wipe off \\
\hline Speed off & Spin off & Yank off & \\
\hline Split off & Sponge off & & \\
\hline Stay off & Stream off & & \\
\hline Strain off & Be struck off & & \\
\hline Tear off & Throw off & & \\
\hline Tick off & Touch off & & \\
\hline Towel off & Trail off & & \\
\hline Trigger off & Trim off & & \\
\hline Veer off & Wander off & & \\
\hline Warn off & Wean off & & \\
\hline \multicolumn{2}{|c|}{ Total: 74} & \multicolumn{2}{|c|}{ Total: $\mathbf{5 5}$} \\
\hline
\end{tabular}

